\title{
Gogol'ün 'Palto'sundan 'Beyaz Mantolu Adam'ı Çıkarabilmek -Nesne'nin Özne Simülakra'sı-
}

\author{
To Take Out the Man in The White Coat From Gogol's Coat \\ - Object's Subject Simulacra -
}

Kadir Can Dilber ${ }^{*}$

\section{Özet}

Nesnenin özneyi ele geçirme adına yaptı̆̆ girişimler; onun arzu ettiği yanıtları vererek, ona inanırmış gibi yapmak ve onu kendi safına sürükleyerek onun yerine geçme çabasından ibarettir. Özne kendisinden kaçamadığı nesnenin bir süre sonra kurbanı olur. Bu durum, bugünün sosyal ağlarına bakıldığında daha net bir şekilde gözlenir. Simülasyonun en belirgin özelliği en önemsiz olguları bile kapsayan gerçeğin yerini alan modellerden oluşmasıdır. Yarattığı karakterler ile simülatif dünyada özneye çıkış yolu sağlayan Dostoyevski, üretim-tüketim çelişkisinde "Hepimiz Gogol'ün Palto'sundan çıktık" diyerek "Palto"yu bir nesne olmaktan çıkarıp Kozmosun yerine koymaya çalışır. Gogol'ün "Palto"sunda nesne, özneyi ele geçirmeyi deneyerek istencini ve devingenliğini kesmeden sürdürür ve en nihayetinde Kozmosun yerine de geçer. Gogol'ün "Palto"su sadece kendi başına bir evren olarak kalmaz aynı zamanda simülatif dünyaya bıraktığı monadlar "Beyaz Mantolu Adam"1 doğurur. Bu çalışma

* Dr. Öğr.Gör., Ahi Evran Üniversitesi Fen Edebiyat Fakültesi Türk Dili ve Edebiyatı Bölümü kadircandilber@, gmail.com 
Gogol'ün “Palto”sundan Oğuz Atay’ın “Beyaz Mantolu Adam”1nı çıkarma girişimi olarak nesnenin (Palto'nun) özne (Beyaz Mantolu Adam) simülakrasını gerçekleştirme, Özne-Nesne ortaklığında (Peter Schlemihl) kozmosu keşfetme girişimidir.

Anahtar sözcükler: "Palto", “Beyaz Mantolu Adam”, "Peter Schlemihl”, simülakra, simülasyon, kozmos

\begin{abstract}
Attempts of the object to take over the subject consist of giving the answers it desires, pretending to believe it, and dragging it to its own side. The subject becomes a victim of the object that it cannot escape. This situation is more clearly observed when viewed in today's social networks. The most obvious feature of simulation is that it consists of models that replace reality, including even the most insignificant phenomena. Dostoevsky, who provides a way out to the subject in the simulation world with his characters, tries to stop "coat" being an object and replace it by Cosmos, by saying "we all came out of Gogol's coat" in the production-consumption Paradox. In Gogol's coat, the object attempts to capture the subject and continues without cutting off its will and dynamism, and eventually replaces Cosmos. Gogol's "Coat”, is not only a self-contained universe but also a monad that he left to the simulators world generate "The Man in a White Coat". This work is an attempt to realize the subject (The Man in a White Coat) simulacra of the object (Coat) as an attempt of Gogol's Coat to take out from Oguz Atay's The Man in a White Coat and to discover the cosmos in the Subject-Object partnership (Peter Schlemihl).
\end{abstract}

Keywords: "Coat", "The Man in a White Coat", "Peter Schlemihl", simulacra, simulation, cosmos

\title{
Kozmos'un Palto'su
}

“Hepimiz Gogol'ün Palto 'sundan çıktık”

Dostoyevski

Devingenlik kendi kendiliğini yitirdiğinde üretim sonlanır ve nesneler sistemindeki hiyerarşi tekrar düzenlenir. Nesnenin işlevini yitirmesi ya da sonlu bir hale gelmesi onu harekete geçiren veya ona önem yükleyen öznenin işlevsizleşmesi problematiğidir. Bu problematik aslında öznenin istenç kabiliyetini yitirmesi ve süreklilikten uzaklaşması ile gerçekleşir. Öznenin duyarsızlık pozisyonuna geçmesi aynı şekilde nesne tarafından algılanır ve etki-tepki prensibi gereğince tepkisizleşir. Kozmosun (Evren) temel özelliklerinden birisi olan “tepkisizlik”, öznenin çaresizliğini de gözler önüne sermektedir.

Öznenin arzu ettiği devinim yine nesnenin kurduğu oyunu tersine çevirmesiyle sağ- 
lanır: "Burada nesnenin stratejisi son derece basittir: Özneye arzu ettiği yanıtları vermek, katılırmış gibi yapmak ve özneyi buna inandırmak" (Adanır, 2008: 17). Kozmosun dinamik ve sonsuz yapısı sonlu gerçeklikte monadlar aracılığıyla varllğıını sürdürür. Sonlu gerçeklikte sonsuz ruh parçasından meydana gelen monadların evrendeki yansıması şekil değiştirerek "simülakra"yı meydana getirir. Simülasyon evreninde "artık her monad, her molekül kalıcı bir görünüm arz eden narsisizmle dur durak bilmeyen imgesel yinelemeler ağına düşmektedir. Artık hiçbir şeyle mücadele etmediği için ortadan kaybolan özne, dünyanın sonu geldiğinde karşılaşacağımız öznellik imgesi işte böyle bir şeye benzemektedir. Özne kendisinden kaçamadığı nesnenin, gerçeğin, ötekinin, bir anlamda artık bu hiçbir şeyin karşı çıkamadığı olayın kurbanıdır" (Baudrillard, 2012: 16). Kozmosun tek başınalığı aslında onu hem özne hem de nesne pozisyonuna sürükler. Dünyanın sonu geldiğinde kozmos nesne pozisyonundan çıkıp kendini özne yapar ve simülakrasını başka bir dünyada devam ettirir.

Kozmosun içinde yer eden parçalar özne, nesne ve bu dolaşımda oluşan enerji olarak karşımıza çıkar. Bu parçalar evrende olabilme ve devamlılık ilkesi ile yaşar. Enerjinin açığa çıkışı öznenin kendini ortaya koyma ve nesnelere karşı takındığı tavırda gizlidir. Özne yetkilerin onda toplanmasını içeren bir güce sahiptir. Bunun sebebi onun dinamik yapısıdır. İşte öznede somut olarak görülen bu durum evrenin en önemli özellikleri arasında yer almaktadır. Etki-tepki döngüsü içerisinde bu arada doğan enerji ile oluşan diyalektik yapı Hegel'i hatırlatır. Tez, antitez ve sentez üçlüsü varoluşunu koruyarak enerjinin doğumuna ön ayak olur. Oluşan enerji ile Leibniz'in, sonul gerçekliği oluşturan, sonsuzluğa işaret eden küçük varlıkları olan monadlar açığa çıkar. Monadlar uyanmaya başladıkları zaman bir diğer monad için harekete geçerler, bu tıpkı elektron ve proton parçacıklarında olduğu gibi, bir çekimle yeni bir şeyi var etmektir. Bu da oluşturdukları her şeyin canlı olduğunu gösterir. Canlılık, hareketlilik ve bir şey olma durumu olsa dahi, her an başka bir şey olabileceği anlamını da taşır. Özsel farklılıkları olsa da birbirlerini etkileyerek birlikte hareket edebilir ve kendilerini yok edebilirler. Var olmak için birbirlerine ihtiyaçları olmasa da var etmek için vardır. Bu döngüsel süreçte evrenin tepkisizlik ilkesi kayıttadır. Evren sadece izler. Dokunuşunu içinde barındırdığı parçaları ile sürdürür. Fakat ondan kopmuş parçalar olarak özne ve nesneler üzerinden Tanrı'nın kurmuş olduğu oyun sürer gider.

Kozmos üzerindeki en önemli duruş güç’tür ve bu gücü elinde tutan kimse iktidar o'dur. Her parçanın yani monadın kurmaya çalıştığı gerçekliğin içinde, bulmaya çalıştığ gücü nasıl elde edeceğini öğrenmesi ile döngü değişir. Bu noktada bütün parçalar ve onların oluşturduğu varlıklar birbirini kontrol etmektedir, yasası ortaya çıkar. Bu durum, bugünün sosyal ağlarına bakıldığında daha net bir şekilde gözlenir. İçerisine girilip süreklilik arz eden nesnel dünya, telefonun kapanmasıyla özneye döner. Sanal bir hareket kazanan öznenin nesne ile değiş tokuşu simülakradır ve bu simgesel yer değişim gerçeğin yerini almaktadır. Nesnenin yer değiştirmesi ile birlikte mutlak gerçek açığa çıkar ve özne düştüğü tuzaktan uyanır. Özne üzerinde ölü numarası yapan nesnenin bu kadar etkin yer değiştirebilmesi simülasyon evreninin gücünü ve hakimiyetini de ortaya çıkarır. "Bunun nedeni 
simülasyon mantığının her şeyi egemenliği altına almış olmasıdır. Bu mantı̆̆ın bir olgular ve nedenler mantığıyla hiçbir ilişkisi yoktur. Çünkü simülasyonun en belirgin özelliği en önemsiz olguları bile kapsayan gerçeğin yerini almış modellerden oluşmasıdır" (Baudrillard, 2011: 35). Gerçeğin yerini modeller alıyor ise Özne'nin varlığ da bir sorunsal olarak belirir. Burada, "Özne nedir?" denildiğinde akla ilk gelen bireydir. Althusser’a göre "Öznenin emirlerine özgürce boyun eğsin, yani kendi tabiiyetinin eylem ve hareketlerini "tek başına tamamlasın" diye birey özgür birey olarak çağrılır (Althusser, 1991: 72). Bu iktidarın kurduğu bir düzenektir. Böylece sonul gerçekliğin içinde yeni bir sonluluk projesi olan simülasyon kurulur ve her yeni doğan buna dâhil edilir.

İdeolojik bir yaklaşım olarak görünen bu bakış, nesneler dünyasına da sıçrayabilir. Çünkü özne kontrolü bırakır ve sunulana kapılır. Artık bu sunum özne konumundadır. Enerjisini onu üretmek için harcayan özne, onu kullanarak kendini unutur ve seri bir şekilde aynı şeyleri tekrarlamaya başlar, dinamiğini kaybetmiş, kontrolü elden kaçırmıştır. Böylece dengeler ters-düz olur. Nesnelerin çarkına kapılan özne, bu sanal oluşumu olmazsa olmaz hale getirir. Onsuz yapamaz. Anlamsızlaşmanın başladığının farkına varmaz ve oyalanmaya devam eder. Nesnenin kullandığı bu güç onu oyalamaya yetmektedir. Bunu yapan iktidar bile olsa nesnenin önüne bir süre sonra o da geçemez ya da önünde duramaz. Çünkü iktidar oluşu tamamen nesneye dayanır. Bu iktidar olma girişimi nedir ve nasıl engellenir? Burada devreye hafiflik girer: “ 'Uçan bir güvercin için hava ve rüzgâr ne anlama geliyorsa, insan için de hiçlik o kadar hayati bir öneme sahiptir.' Kant'ın verdiği örnekteki hafif güvercin her türlü direnci alt ettiği takdirde daha iyi uçabileceğini düşünmektedir" (Baudrillard, 2012: 6). Bu anlatı içinde saklanmakta olan bir yaşam savaşımının yoluna koyulması değil midir? Hafifletmek, düzene koymak gibi düşünülebilir. Bu noktada anlatı içindeki karakterlerin tavrı ile kozmosun onlara yüklediği işlevin çatışmasından doğan simülatif bir çarpışma döngüsüne dönüşür. Bu çarpışma evreninde gerçeğin yerini alan modeller evreni yani hipergerçeklik düşsel - kurmaca olan yok olurken bir gerçeklik oyunu ile karşılaşıllır. Sanat sonsuz bir yeniden-üretim süreci içine girerek, bu gündelik ve sıradan bir gerçeklik bile olsa, kendi kendinin yansımasına dönüşebilen her şey sanata dönüşerek, estetik bir boyuta sahip olmasına yol açmaktadır (Baudrillard, 2008: 135). Sanatın gerçeğin kendisi olma ereği simülasyon evreninde ölür, nedeni ise artık gerçeklik etkisinin yaratılabileceği zamanın ortadan kalkmış olmasıdır. Kozmosu kaplayan simülasyon ağından kurtuluş yok mudur?

Kurtuluşa giden yol, bir arayışın temsili değerlerini ortaya koyan edebî dünyadan geçer. Bu sonsuz bir kurtuluş değildir, çünkü sürekli olarak bir öncekinden doğan yenilikler - açığa çıkmayı sürdüren monadlar gibi- çıkagelir. Bunların hiçbiri sonsuz değildir ve aksine bir tuşla işi bitecek şekilde hazırlanır. Buna rağmen kaosu sürdürecek güce sahiptirler.

Bazı küçük örneklerle simülakrlar anlatılsa da kozmos simülatif bir sistemle kuşatılmıştır. Evren örneğini kendisi olarak dile getirir. Edebi olan, nesnenin özne simülakrasını daha kolay anlaşı1ır hale sokar. Örneğin Alice'in tavşan deliğine girmesi ile birlikte 
simülatif bir evrenin kapıları açılırken oradaki nesnelerin özneleştiği, öznelerin ise nesne pozisyonuna sürüklendiği görülür. Alice'in kozmosunda sadece nesneler sistemi yer değiştirmez aynı zamanda özneler de simülatif bir görüngüye sahip olurlar: "Hayret! Sirıtmayan bir kedi görmüştüm pek çok kez' diye düşündü Alice, 'ama kedisiz bir sırıtma! Bu ömrümde gördüğüm en tuhaf şey!" (Caroll, 2009: 87). İskambil kartlarının özneyi ele geçirmesi ile başlayan süreç "bir deste kâğıttan başka nesiniz, söyleyin" (Caroll, 152) ifadesiyle son bulur. Bu durumda gerçek de hipergerçeklik de tamamen emilerek dönüşüme uğrar. Hipergerçeklik kendini oluşturan simülakr, ayrıcalıklar ve önyargılar düzeyinde, karşılıklı değiş tokuş yoluyla, hem sanat hem de gerçeğin ulaşabileceği en üst aşamayı tercih etmektedir (Baudrillard, 2008: 132). Kısacası Alice, sonlu gerçeklikten sonsuza uzanır. Alice'in açttğı pencere burada çok önemli bir rol oynar. Her şeyin ters düz edildiği bir dünyada karakterlerin ağırlığı ve öznenin devingenliği sanatın estetik yönünün güçlenmesini sağlar.

Cervantes' in Don Kişot isimli eseri öncelikle nesnel bir yaratımdır. Don Kişot karakterinin istenci ve direnci simülatif evrende öznenin "ben burdayım, okuduğum kitaplarla kurduğum dünyanın kahramanıyım, harekete geçip dünyayı keşfetmenin zamanı geldi” diyebilmesi, kendi farkındalığının üzerinden kendi üretimini sağlaması sonlu gerçeklikte sonsuz sayıda monadlara dönüşmesini sağlar. Don Kişot karakteri simülasyon evrenine balyozla darbe indirir ve evrenden kaçış için özneye hareket sahası yaratır. Cervantes bu sistemin varlığına kurguyu ters düz ederek değinir ve özneye şöyle seslenir: "Aylak okur: Bu kitabın, zihnin düşünülebilecek en güzel, en zarif, en akıllıca ürünü olmasını isterdim; buna yeminsiz inanabilirsin. Ancak tabiat kanununa karşı çıkamadım; tabiatta her şey, benzerini doğurur. Benim kısır gelişmemiş zekâm da, her türlü rahatsızlığın hâkim olduğu, her türlü hazin sesin duyulduğu bir hapishanede doğmuşçasına kuru, k1rışık, maymun iştahlı ve çok çeşitli kimsenin aklına gelmeyecek düşüncelerle boğulmuş bir evlattan başka ne doğurabilir?..." (Saavedra, 2005: 9). Doğacak olanın hiçliği yaratılan karakterin tabiatın yarattıklarının sınırlarıyla belirlenmesi ile orantılı olacağından buradan çıkan yaratımın da simülasyon dünyasında daha önce yaratılanlardan pek farklı olmayacağını ancak ona yüklenen bazı şeylerle farkındalık yapacağının belirtilmesi okurun yani öznenin uyandırılması açısından önemlidir. Çünkü edebî karakterlerin yarattığı farkındalık sayesinde özne kendini simülasyon evreninden çıartarak örülmüş tüm sanal gerçeklerden sıyırır ve nesnenin akıl almaz oyunlarından kendini kurtarır. Öznenin hiçlik çekirdeğinde kendini yok olmaktan kurtarabilmesi metalaşan dünyaya üretimsel bir gerçeklik kazandırmasıyla sağlanabilir.

Yarattığ karakterler ile simülatif dünyada özneye çıkış yolu sağlayan Dostoyevski üretim-tüketim çelişkisinde "Hepimiz Gogol'ün Palto'sundan çıtık” diyerek bizi başka bir yazarın dünyasına kanalize eder. Her yazarın idealar evreni karakterlerin simülakrası ile gerçeğe yaklaşır ya da uzaklaşır. Bir hikâyenin nesnel bir evrenden çıııp öznenin simülakrasını ele geçirmesi ve çıkıp geldiği hiçliğe yeniden karışması "Palto" isimli hikâyede tam olarak gerçekleşir. Kozmos ile eş değer görülen "Palto" bir nesne olmaktan çıar ve öznenin kendisi olur. Palto, istencini ve devingenliğini kesmeden sürdürür ve 
Kozmosun yerine geçer. Burada Gogol'ün dehası ve simülasyon dünyasına girme çabası göze çarpar. "Burun" hikâyesi ile ilk girişimi yapan Gogol, o dünyanın camdan yapısını "Palto" ile kırar. Özne her ne kadar simülakra söz geçirmeye ve gerçeğe yaklaşmaya çalışsa da nesne üzerinden bu yapıyı aşmak her zaman daha kolaydır. Çünkü simülasyon evreni nesne ile özneyi ele geçirmeyi dener ve ona sürekli oyunlar oynar ki bazen ölü taklidi bile yapabilir. Eğer nesne kontrol altına alınır ve varoluşsal bir çerçeveden bu üretim yapılırsa evren aşkın olabilir. Palto" artık bir nesne olmaktan çıkıp özneye hatta oradan Kozmosa kadar uzanır. Kozmos'un Palto'sunda 'nesnenin işlevini yitirmesi ya da sonlu bir hale gelmesi onu harekete geçiren veya ona önem yükleyen öznenin işlevsizleşmesi problematiğidir.' ifadesi varoluş kaygısından doğar. Her şey bir yerde, bir anlamda varolma yükümlülüğü ile dile gelir. Bütün bu döngü içinde her şeyin vardığ 1 ana nokta varoluş problematiği olarak karşımıza çıkar.

Nabokov'a göre "Palto" sanıldığı kadar basit ve tek düze bir hikâye değildir: "Hikâyenin gerçek değerini takdir edebilmek için, bir tür zihni parende atıp edebiyatın basmakalıp değerlerinden kurtulmak, insanüstü hayal gücüyle düşsel bir yola düşmüş olan yazara eşlik edebilmek gerekir. Gogol'ün dünyası bir ölçüde, modernfiziğin 'Genişleyen Evren' ya da 'Patlama Evreni' gibi kavramlarıyla bağlantılıdır; geçen asrın pürüzsüzce dönüp duran dünyalarıyla alakası yoktur. Edebi tarzı, tıpkı uzay gibi bükümlüdür” (Nabokov, 2012: 135-136). "Palto" simülakrası öykünün derinliğinde bükümlü bir hal alır ve kendi kendisine yeni bir yol çizmeyi dener. Karakteri alt etmeyi başaran "Palto" önce nefes almaya başlar ardından da tüm evreni içerisine alarak genişler. Bu genişleme süreklilik arz ederek ilerler ve simülatif dünya artık gerçek dünyaya kapı aralar. Palto'nun içerisine girebilmesi gibi oradan çıkabilme varsayımının gerçekleşme direnci de süreklilik arz eder.

Tıpkı nesnenin tanıdık hale gelip eski yerini kaybetmesi gibidir. Keşfedilmemiş bir ada artık bulunduysa o halde keşfedilmemiş olma özelliğini yitirir ve diğerleri gibi olur. Sıradanlık burada göze çarpar. Bu bir nevi kaybolmayı da ifade eder. Baudrillard da bunun bir tür ortdan kaybolma olduğunu ileri sürer: "Burada söz konusu olan şey ortadan kaybolmaktır, yoksa tükenme, yok olup gitme ya da ortadan kaldırılma değil. Kaynakların tüketilmesi, türlerin yok edilmesi gibi şeyler fiziksel şeyler ya da doğal olgulardır" (Baudrillard, 2012: 8). Diğerlerine benzetme adına bütün insanlara ortak bir senaryo sunulur. Assl olan, tek görünüş, tek beyin, tek bir duruştur. Bu bir meta yaratmaktır ve inandığımız tanrıdan daha evrenseldir. Diğerleri gibi olmak adına herkes aynı mağazaya, aynı sokağa koşar. Bunu masum gösteren illüzyon ise yaşama çabasıdır. Öyle bir çaba ki, seni sen olmaktan alıkoyan, güdülebilen, kullanmaya hazır, cansız mankenler topluluğu kurar. Bu toplulukta herkes modeldir ve anlamı üzerinde taşıdığ 1 şey'e yükler. Bedenler kokuşmuş, pörsümüş ve bütün özneler bununla kuşatılmış durumundadır. Nesnenin kovuğu burada özneye kucak açar. Özne ister istemez orada sığıntı olarak yaşamaya başlar. Özneler yerine, sokaklarda nesneler boy gösterir. Nesnenin evrensel kimliği burada meydana çıkar. Bulaşııı bir tezgâh kurulmuştur ve çamurunu her yaşama sıçratır. Nesnenin gözetimi altında, onu aşmak için her seferinde yeni bir yol aranır. Bunlar yeni 
simülasyonların habercisidir. Tapınma artık arzuların körleşmesi ve farkındalıkların yok olması ile yapılan bir eylem olur ve belirsiz bir şekilde hâkimiyetini sürdürür. Bu belirsizlikten hareketle şöyle bir varsayıma gidilebilir; bu evren belki de, tahmin bile edemeyeceğimiz küçüklükte bir parçacığın düşüyken, düş kurmaya başladıktan sonra başka başka şeylerin parçası olduğunun farkına varır. Bu parçaların bir arada kurmuş olduğu bütünden tüm evreni kaplayan bir örtü doğar. Bu örtü, gizil güçleri temsil eden monadların belirli sınırlarla kendini açığa çıkardığı yerlerde kozmosu tanımlar. Ve sonsuz gerçekliğe anahtar olan sonlu gerçekler kurar. Herkes bu örtünün gölgesi altında varlığından bahseder. Bir süre sonra onu kuşatan bu örtü de kendini kaybeder.

"Palto" öznenin yerine geçtiyse ve sonsuz olana ulaştıysa etrafımızdaki ruh parçacıkları başka bir nesneyi ele geçirmek için mutlak gerçeğe ulaşmayı dener. "Palto" evreninden başka bir evren yaratabilmek mümkün olmasa da yarattığı dalgacıklar koca bir okyanus oluşturabilir: 'Gogol'ün dehası Palto'da sergilediği sanat, paralel doğruların kesişmekle de kalmayıp, solucan gibi kıvrılabileceklerine, karmakarışık hale gelebileceklerine işaret eder; tıpkı suya yansıyan iki sütunun, gereken dalgacığı yakaladıklarından titrek titrek burdukları gibi" (Nabokov, 136). Oğuz Atay, öyküleri ve karakterleri ile de kendi evrenini yarattı̆̆ gibi "aura"sını da oluşturmayı bilir. Gogol gibi majör edebiyata yans1maları olmasa da Atay, kavramlar ya da özne üzerinden simülasyon dünyasında estetik olanı yakalamayı başarır. Atay'ın "Beyaz Mantolu Adam”ı nesneden özne simülakrasını deneyen Palto hikâyesinin aksine özneden nesne simülakrasının denendiği görülür. "Beyaz Mantolu Adam" nesne ile metalaşan üretimden tüketime geçen özneye geçişi sembolize eder. Gogol'ün Palto'su sadece kendi başına bir evren olarak kalmaz simülatif dünyaya bıraktığı monadlar "Beyaz Mantolu Adam" doğurur. Bu çalışma Gogol'ün "Palto"sundan Oğuz Atay'ın "Beyaz Mantolu Adam"ını çıkarma girişimi olarak nesnenin (paltonun) özne (Beyaz Mantolu Adam) simülakrasını gerçekleştirme, Chamisso'nun "Peter Schlemihl” ile Özne-Nesne ortaklığında kozmosu keşfetme girişimidir.

\section{Palto'da uyanan ordu}

Gölgenin palto şeklini almış kozmosun göbeğinde öznesini edebi metinlerde arama girişimi sonuç verir ve Akaki Akakiyeviç'in karakter olarak doğumu gerçekleşir. Sıradan bir devlet memuru olan Akaki "Pek göze çarpmayan bir memur; boyu kısa, yüzü hafif çiçek bozuğu, kızılımsı, hafif çipil gözlüydü; kafasının küçük bir kısmı çıplak, iki yanağı da kırışıklar içinde, yüzü, kara-sarı denilen renkteydi” (Gogol, 1999: 33) olarak tanıtılır.

Akaki'nin yaşamında da yaptırım gücü doğadan gelir ve doğanın hareketleri ile değişen yapısı bize birtakım tepkiler verdirir. Etkiye verdiğimiz tepki karşısından olay tek düzlemde kışın soğuğu ile gelen giyinme problemidir. Yüzeyde böyle varsayılabilir ya da görünebilir ancak ihtiyaç nesnenin kuşanmış olduğu gölge üzerinedir. Bu Bay Akaki'de olmasa da zamanın ve özne müsveddelerinin onun üzerinde uygulamış olduğu evrensel giyim kuşam tarzıdır. Herkes jilet gibi dikkat çekici, hoş, temiz, bakımlı olmalı ve tüm bunlar olurken de diğerlerine benzemeyi ihmal etmemelidir. Neden diğerleri gibi 
olmak ya da benzemek endişesi yaratılır? Tüm evren, gel seni bizim gibi yapalım, der gibi bakmaktadır ya da oyunu kendine göre kurmaktadır.

Farkındalığın ölüm tarihi olarak nesnenin evrensellikte zirveye çıkışı gösterilebilir. Anlam yitimi, klonlanmış varlıklar gibi gezme, simülatif dengenin kuruluş tarihi olarak da kayda geçer. Çünkü aslı astarı olmayan, suyun üzerindeki gölgesi sadece orada olduğu sürece devam edecek olan bir şeyden bahsedilmektedir. Tüm bu inşa edilen sistem, özünde olan 'şey' dışında gerçeklikten kopuktur. Özde su, hava, toprak ve ateş vardır. Kozmosun kaynağı olan bu dört temel unsur, imitasyonların doğmasına da mani olmaz aksine yardımcı olur. Ortaklaşa bir yaşam ve ortak kullanım alanları, ortak fikirler, aykırı düşünme yasağı, başka türlü olmama gayesi, hepsi bir aradadır. Ortaklaşa yenilikler sistemi bireyi ayakta karşılar. Orada aslında; "Hadi peşimden gel" demek ister fakat bunu demek yerine doğrudan uygulamaya geçer. Sonrasında benim hissim, benim rengim, benim düzenim, benim modelim benim, benim, benim diye herkes sarılıverir. Mesele anlam yüklemek değil aksine sürü haline getirilmiş bir psikoloji yaratmaktır.

Bir özne hayal edilir ki o, kaybettiği paltosunu aramaya çıkar. Palto, işlevi itibariyle yüklenmiş olma özelliğini taşır. Özne ise ona anlam yüklemesi ile vardır ve bu bir modele bakılmaksızın duyulan manevi bir bağl1lıktır. Devamında bir model yaratılır ve artık herkes o'dur. Model meta'laşma yolunda ilerlerken diğerleri de simulakrları olarak çoğalır. Sayıları her geçen gün biraz daha artmaktadır. Bu narsistik tavra ne kadar yakındır? Görünen o ki hiçliğe hiç kadar yakındır. Çünkü narsisizmde kendine varma varken, sürüleşme de kendinden uzaklaşma ve yaygınlaşmakta olana yönelim vardır. Kendinde olma Akaki'de yerleşik bir görünümdür. İç dünyasından ne yazarının ne okurun ne de etrafindaki karakterlerin haberi yoktur. Onun kendi halinde bir kâtip olduğu bahsi hep gündemdedir ve kötücül olan ise her seferinde ona dokunmak için firsat arar. Bu firsatı da rahat bir şekilde yakalar çünkü Akaki yaşamın devamı için sistemin içine dâhil olma girişiminde bulunmuş bir varlıktır. Varlıktır, çünkü sadece vardır, başlangıçta ne anlamda var olduğu belirsizdir tıpkı diğerleri gibidir. Sisteme dâhil olan ya da edilen simülasyon parçalarından farkı nedir öyleyse?

Kabuller doğrultusunda bakıldığında doğan her insan Özne'dir. Bu sebepledir ki kimse özne olmak adına hiçbir şey yapma gereğinde bulunmaz ki bu durum yaratım olarak kurgusal varlıklar olan karakterler için de böyledir. "Ben zaten özneyim" bakış1 önüne konulana uzanır ve hazır halde sunulur ele geçirir; giyer, alır, yer, bakar ve sever, başka türlüsü de düşünülemez. Akaki'nin kaderi de yazgısı da bundan nasibini alır çünkü yazarın evreninde simülatif olarak tasarlanmış bir nesnedir, sadece kendi evreninde özne pozisyonundadır. Akaki sorgusuz sualsiz, maddesel şeylerin kaygısı dışında bir şey düşünmeden bulunduğu evrendeki arzusu gayet masumdur: Üşümeme arzusu. Bu arzu öznede varolagelen bir eksiklikten kaynaklanır ve bu eksikliği kapatacak bir nesne arar. Doğanın işbirliği sayesinde nesne pozisyon değiştirmek için bekler ve Akaki'i simülasyona dâhil eder. Özne'nin nesnenin peşine takılması ve ondan bir şey beklemesi ölü taklidi yapan paltoyu uyandırır ve artık nesne farkındadır. Nesnenin özne simülakrası işte 
tam burada gerçekleşir ve uyanan monadlar arac1lığı ile palto öncü bir kimliğe bürünür. Kendi simülasyonlarını yaratmaya başlayan nesne, özne olanı etrafinda pervane ederek iktidar gücünü kendi çarkına takar ve daha fazla dönmesi için ona istediği her şeyi vermeyi amaçlar. Özne ilk anlamıyla burada ortadan kalkar ve geldiği yere yani hiçliğe geri döner. Bir yok olma değildir bu, aksine silinmedir, etkisizleşme, bir nevi cansız mankenler yaratımıdır ve artık özne nesnenin kovuğuna yerleşmektedir. Bu dondurulmuş yaşam içinde, zamanın ve mekânın ne önemi vardır? Varlı̆̆ın bu şekildeki ifadesi için ölü veya diri olmak fark eder mi? Yaşamdan söz etmek bu denli zorken ölme eylemi ne kadar gerçektir. Gerçeklerle bu derece karışan simülatif sistem Akaki' in yaşamını da alabora eder. İstilaya uğrayan Akaki sözlü veya görsel olarak her türlü tacize maruz kalır.

Göstergelerin dünyasında nesnenin egemenliği altında ilerleyen görünüş, nesnenin havasına kapılan her öznenin ulaşma arzusuna kapıldığı tek gerçek haline gelir. Nesnenin verdiği gölge ile Akaki artık büyük bir tehlike içindedir çünkü karanlıkta bütün 1şıklar onu işaret etmektedir. Akaki evrenin dinamik yapısını üzerine alır ve salınmaya başlar. Artık palto onun mevcudiyetinin yegâne varlık göstergesidir ve yağmalanan bütün modeller gibi o da yağmalanmaya mahkûmdur. Bu yağmayı kaldırabilecek güç onda yoktur çünkü fazlasıyla kendindedir ve kendinde olarak kalır. Öznenin yaşam ritmi nesnenin DNA's1 ile uyuşmaz fakat onu sevmektedir. Çünkü palto, Akaki’nin diğerlerinin arasına girmesi için tek kullanımlık ilk ve son biletidir. Aslında olması gereken olur ama Akaki için her şey sanki tersine dönmeye başlar. Nesne yani palto sadece Akaki’i ele geçirmekle kalmaz diğer özneleri de cezbeder ve kovuğa girmeye davet eder. Akaki’nin memur arkadaşları ile katıldığı davetten evine dönerken, paltosu çalınır ve burada çalınan sadece bir nesne olan "palto" değil aksine Akaki'nin bütün varlığıdır. Artık görüntüsünü kaybetmiş ve hiçliğe hızlı bir şekilde sürüklenmekte olan karakter için son önceden bellidir. Burada şunu iyi ayırt etmek gerekir olmayan bir görüngü, kabul edilmemiş ve üzerinde iğreti duran bir paltosuyla bir adam, yani nesne pozisyonuna sürüklenmiş bir özne simülakrası, istenç ve devingenlik kazanamaz. Nabokov'un dediği gibi: "Bu dünya olduğu gibidir ve onu yok edebilecek her şeyi dışlar; öyle ki her tür düzeltim, mücadele, ahlaki hedef ya da girişim, bir yıldızın yörüngesini değiştirmek kadar imkân dışıdır" (Nabokov, 2012: 135). Olduğu gibilik, istenç ve devingenlik özne olarak dünyayı kendi kendisi olma bilincine sürükler, özne olarak dünya ne nesneye kendini teslim etmek ister ne de dişarıdan gelebilecek benzeşimlere yenik düşer.

Dikkat edilirse eserin isminin bir karakter adı değil de bir nesne olduğu ancak bu nesnenin de canlı bir şekilde yazarın tasarımı olarak sunulduğu görülür. Akaki’nin tam yaşamak üzereyken kıyısından döndüğü yaşantısı, paltoyu kaybetmenin verdiği üzüntüyle birlikte gelen hastalıkla son bulur. Ölümü normal değildir ancak normal süsü verilir; çünkü onu alt eden bir hastalıktır. Burada onu ele geçiren ve yok eden nesnenin onu kaldırmış olması ihtimali kimsenin aklına gelmez. Bedenini ele geçiren nesne, kendini iktidarın hazzını yaşarken geride bıraktığı özne, davası bir hiçlik olan simülatif parçaların bir araya getirdiği bir varlık olarak silinir gider. Denildiği üzere: “... o büyük adamı bıraktık. Oysa o, yüzde yüz gerçek olan öykümüzün tuttuğu bu olağanüstü yolun asıl 
sorumlusu sayılabilir" (Gogol, 46). Büyük adamın hikâyeye dâhil olması ile birlikte karakterin çöküşü başlar, talihsiz kaybının ızdırabını bu büyüklügün karşısında daha derin hisseder. Hiçbir şey ona teselli vermez aksine onu daha da bitirir. Bu bitişin sorumlularından biri olarak büyük adama önemli bir pay düşer. Öyle ki anlatının devamında vicdan, ne kadar büyük olursa olsun bu adam, yakasını bırakmaz. Bu vicdan meselesi hâlâ istediğini alamayan Akaki'nin çırpınışını da temsil eder.

Evet, nesne Akaki'yi ele geçirip dönüştürür ancak o, kaybettiği varlığıyla -paltonun simülakrası olması ve çalınmasıyla yok olması- birlikte yeniden bir yaratım olarak okurun yani dışsal öznenin üretimi olarak tekrar metne dâhil olur. Artık Akaki, metaların gölgesi altında kalmış bir post olarak vardır. Onun simülasyon dünyasından gerçek dünyaya ileteceği işık ölümüyle yayılmaya başlar. Artık nesne olan uzaklaşmak ister, o ise akışkan bir gerçek olarak kendine uygun bir gölge buluncaya kadar da paltoların peşini bırakmaz. Metni okuyan dışsal özne artık bilinçlenmiş nesneler sisteminin sonlu dünyasında simülasyon olarak yaratılan, rol yapan ve onu ele geçiren "palto"ların peşindedir.

\section{Beyazımsı illüzyon}

Oğuz Atay'ın nesneler dünyasına doğrudan giriş yaptığ1 "Beyaz Mantolu Adam" hikâyesi öncelikle bir illüzyondur. Sadece kutuplardan rahatlıkla izlenen kutup 1şıklarının senfonisini renkli bir şekilde okura yansıtırken aslında bunun Güneş’ten gelen bir gaz salınımı olduğunu yani toplumun değişen düzeninde maddenin hüküm gücünü gözler önüne serer. O yani Beyaz Mantolu Adam kalabalık bir topluluk içinde tanımlanan ve öznenin kabiliyetlerinden arınmış biri olarak tarif edilmeye uğraşılan, garip bir şekilde tasavvur edilen, ortak olamama, eksik kalma durumları ile kuşanmış bir özne olarak hareket eder. Toplum herkesin ortaklaşa yaşam alanını temsil etmesine rağmen o, bu yaşam alanına sadece bakar, anlam verilememekle birlikte, yadırganır bir tavra bürünür. Burada toplum yani tümel, sistemini simülatif olarak kurduğu için tikele iki seçenek sunar: ya içselleşirsin ya da dışsallaşırsın. Beyaz Mantolu Adam herhangi biri gibi davranıp bu düzene dâhil olmak yerine hiç kimse gibi davranır-davranmaz. Yani tümelin simülatif evrenine hem girer hem de girmez.

Bu süreç şöyle gerçekleşir: Öncelikle bir adam vardır adı ve ne iş yaptığı belirsizdir, hatta kendi farkındalığından da habersizdir. Tümelin ona bakışı hiçlik ile kötücül arasında, düşmüş, ezilmiş ya da terkedilmiş görüngüsünde ilerler. “... parası olmadığını söyleyerek köylü taklidi yapabilirdi; fakat konuşmadığı için, bu bakımdan da başarı kazanması oldukça güçtü" (Atay, 2010: 10-11). Bütün teşebbüslerden yoksun bir şekilde etrafta gezinen ne olduğu belirsiz bir cisimdir. "Kadın onun yüzüne bakarken, bilerek ya da bilmeyerek hiç oynatmamıştı gözbebeklerini. Bu yüzden ilk müşterisi onu kör sanmıştı" (Atay, 2010: 11). Özne kendi içerisinde eylemsizlik sözleşmesi yapmış gibidir, hem öznelere hem de nesnelere karşı alınan estetik bir tavırdır. Dünyaya gelmeyi bu sözleşmeyi imzalayarak kabul etmiş ve kurulmuş evrende kurgusal dünyanın gerekliliklerini yerine getirmeyi bile unutmuştur. O sıfır seviyesinde arafta kalmış bir karakterdir: Hem nesnedir hem de öznedir. 
Öznenin devingenliği olmasına rağmen simülatif evrende söz sahibi değildir çünkü değerler sistemi bu evrende nesne üzerinden şekillenir. Nesneye karşı hiçbir beklentisi olmayan öznenin yolunu ölü taklidi yapan BEYAZ MANTO keser: "Hafif bir rüzgâr çıktı; iriyarı, esmer ve görünüşü taşralı satıcının elbiselerini belli belirsiz dalgalandırdı. Yalnız beyaz manto kımıldamadı; ağır bir kumaştan yapılmış olmalıydı. Bir süre durdular mantoyla karşılıklı. ... Manto vücuduna yapıştı" (Atay, 13). Cebindeki tüm paraları (nesneleri) vermesine rağmen tam karşıllı̆ını çıkaramaz. Özne için bunun önemi yoktur, çünkü cebindeki (nesne) ile hiçbir zaman bir ünsiyeti olmamıştır. Nesneye sahip olan diğer Öznenin karşıllı̆ını bulmadan elindeki nesneyi (beyaz manto) başka bir Özne'ye verme niyeti yoktur ama Özne'nin direnci sayesinde bir kadın manto olan bu nesneyi istemeyerek de olsa teslim eder.

Burada kutup 1şıkları gibi manto da bir illüzyondur. Manto ona yaklaşımı daha çekici kılar ve sonunda o kalabalık topluluk yanından geçip gitmek yerine durup onu izler. Simülasyonda uyanan yabancı varlık bir illüzyon gibi herkesi etki altına alır. Nesnenin ele geçirme oyunu farklılaşır, bu sefer nötr olanın üzerinde ilerleyerek özneyi ele geçirmeyi dener. Bu başarılı girişim ilk başta özneyi değiştirir, söz sahibi yapar hatta aranılan istenilen ve ihtiyaç duyulan bir varlığa dönüştürür. İşte burada bu gücü sağlayan sihirbazın şapkasıdır ve beyaz manto özneyi ele geçirip nötr olanı da ele geçirerek ismine bile sahip olur. O, olan adam artık BEYAZ MANTOLU ADAM olarak yani nesnenin hâkimiyetini girip bütün her şeyi ile dönüşen başka bir varlık haline gelir. Simülasyon burada başlar, özneler değişmeye, iktidar tikelleşmeye ve nesneler sistemi üzerinde değerler kategorizasyonu işler. Özne artık değişmiş nesne olmuş onun simülakrasını yaşamaktadır. Kadınsılık ve beyazlık (saflık) öznenin cinsiyet sorunsalını da doğurur fakat o, bütün bunlardan habersiz silikleştiğinin ve hiçleştiğinin farkındadır.

Son sahnede Beyaz Mantolu Adam tümelin içerisinde kaybolmuş vaziyette yarg1lanmaktadır. Kimdir bu özne, üzerindeki nesneyi çıkarsın diyen özneler bile nesnelerin bedenlerini sardığından habersizdir. "'Mantosunu çıkarsın!' diye bağırdı ön sıradan biri, vücudu kumlarla sıvanmış gibi kıllı bir karaltı. 'Belki de içinde bir şey yoktur,' dedi mahzun görünüşlü bir genç, yanındakine. Ben buna benzer bir şey okumuştum bir yerde" (Atay, 2010: 23). Öznenin girdiği nesneler sisteminde kaybolduğu doğrudur ancak bunu tespit edebilmek için oradaki öznenin 'ben buna benzer bir şey okumuştum bir yerde' ifadesini içselleştirmek gerekir. Belli ki o oradakilerden farklıdır ve Beyaz Mantolu Adam için bir şeyler yapma istencine sahip özne'dir. Böyle bir şeyi okumuş olması simülasyon evreninden uyanması yeterlidir ve bu öykünün sonunu bilen tek karakter olarak bu evrenden çıkış yapacaktır. Beyaz Mantolu Adam artık nesnenin ona oynadığ 1 sonu yaşayacak ve simülatif evrende yok olup gidecektir. Tümelin bakış açısı adam için sorgulandığında ne'lik devreye girer ve tıpkı suyun içerisinde varlığıyla yokluğu arasında kaybolması gibi yiter özne:

"Bir yerden söz ettiğim sırada o yer ortadan kaybolup gitmiş oluyor.

Bir insandan söz ettiğim sirada o insan ölmüş oluyor. 
Zamandan söz ettiğim sırada akıp geçmiş oluyor.

Bu durumda insanın ortadan kaybolup gittiği bir dünyadan söz edebiliriz" (Baudrillard, 2012: 7).

Özne farkına varıp ‘ben bunu bir yerde okumuştum' dediği anda Baudrillard'ın 1srarla üzerinde durduğu gibi zaman akıp geçmiş oluyor, insanın ortadan kaybolup gidiyor. Sonuç olarak karşımıza simülatif olarak yaratılmış bir evren, simülakra'lar ve farkına varamadığımız nesneler sistemi ile her şeyi kontrol altına almış şey’ler düzeni çıkıverir. Öznenin hikâyesini okuyan ya da dinleyen başkalaşmış özneler "amma da hikâye" (Atay, 24) deyip oradan hızlıca uzaklaşıp nesneler evrenine tekrar geri dönerler. Karşımızda hiçliğin içerisinde doğup nesneler sisteminde kendi kendiliğinde yiten beyaz bir illüzyon kalır. Bilmeyiz ki kutup ışıklarının o muhteşem şovunu sağlayan zararlı bir gazdır ve her geçen gün gerçek dünyayı tehdit etmektedir.

\section{Simülakra'ların çarpışması}

Şimdiye kadar kurgusal evrende simülatif olarak yaratılan iki karakterin nesneler sistemini nasıl ele geçirdiğine değinirken aslında gerçek dünyada olan şey’lerin fiktif yapıları ile simülasyon evrenine giriş yaptık. Ancak sahne iki edebi eserden fazlasını içermektedir ve bir diğer palto bizi evrenin kendisi yapmak için zorlamaktadır. Bu rol yapan ya da ölü taklidi yapan değil aksine Tanrısal vasıfları ile özneyi baştan çıkaran bir nesne pozisyonunda bulunur ve bu mesafeden özneyi tamamıla etkilemeyi becerir. Bu gözlerden uzak bir yazarın tasarımlar evrenine attığı ve sesini çok duyuramadığı Peter Schlemihl'in öznesini yitirdiği öyküdür. İki öyküyü birbiriyle çarpıştırıp simülasyon evreninde nesnenin özne simülakrasını karşılaştırmayı denerken Peter Schlemihl ile simülasyon evreninden bir sentez çıkarılması amaçlanır.

Öncelikle Dostoyevski'nin hepimizin içinden çıktığını iddia ettiği Palto'yu ele alırsak Akaki'nin özneden nesneye geçme aşaması yeni bir paltoya sahip olması ile başlar. Yeni paltosunu eline aldığı zaman benliğini toplum tarafından kabul edilişinin belgesini eline almış bulunmaktadır. Metalaşan dünyada ona bu duyguyu çevresindeki gölgeler vermektedir. Paltoyu diken Petroviç'in gururla paltoyu giydirmesi simülatif dünyanın kapılarını açan illüzyonist edasıyladır. Bu illüzyon Akaki’nin üstünde taşınmaya başlar: "Yeni paltoyu görmek için hep birlikte askılığa koşuştular" (Gogol, 1999: 40). Akaki’i dünyalarına buyur etmek için imgeye ihtiyaç duyan arkadaşları paltoyu gördükten sonra selamlayıp kutlamaya başlarlar. Eski paltosunu artık çıkarmıştır, yeni platosu ona yeni bir gölge, yeni bir Akaki olmasını sağlamıştır. Ruhunun derinliklerine kadar bilen eski paltosu özneliğini temsil etmektedir. Artık öznel(l)iği dört duvar arasında sıkışıp kalır: "Son ikisini yan yana görmek için eski paltosunu çıkarıp baktı, güleceği geliyordu; arada ne büyük ayrım vardı yarabbi, ne büyük ayrım” (Gogol, 1999: 40). Eski paltosuna arkadaşlarının deyimi ile palto demeyi hak etmeyen olsa olsa sabahlık olabilecek paltosuna artık onların gözüyle bakmaya başlar. Artık Akaki öznelikten nesneliğe dönüş evrimini tamamlamaya başlar. Kozmos artık ona istediğini verir, yeni bir paltonun oyunun içine 
dâhil olması için önündeki yollar açılmış olur. Paltosunu çaldırdıktan sonra hastalanıp, yatağa düşmesi ve hayata gözlerini kapayarak - "Sanki bu kentte hiç yaşamamıştı. Kimsenin koruyup gözetmediği, yakını saymadı̆̆ı, yabancı bir sineği bile iğneleyip mikroskopla inceleyen savsaklamayan bir doğa bilginin bile ilgilenmediği bir varlık, yitip gitmişti” (Gogol, 1999: 45) -varoluşunu tamamlamadan gitmesi bu görevi paltoya yüklemektedir. Artık şehrin sokaklarında yeni öznelerini arayan paltolar gezmektedir.

Şehrin sokaklarında gezen paltonun biri Oğuz Atay'ın Beyaz Mantolu Adami'nda can bulur: "Rüzgârın ya da gelip geçenlerin salladığı beyaz manto süründü yüzüne. Uzun ve aydınlık bir manto. Kloş etekli, kocaman düğmeli bir hayalet; geniş yakalı, serin" (Atay, 2010: 13). Almak istediği zaman satıcı tarafından dalgaya alınmaya başlar ve satıcı üstüne mantoyu giydirdiğinde dünya kloş eteğin çevresinde dönüyor hissi verir. Paltoya sahip olduğu zaman insanlar tarafindan fark edilmeye göz hapsine alınması kaçınılmaz olur. Özne nesneleşir ve insanlar tarafından dışlanan yabancı olarak görünen adam mantoya sahip olduktan sonra sadece öznesine değil nesneye de yabancılaşır. "Manken" dedi şişman dükkâncı gene, başka söz bulamadığı için. Bir süre de tezgâhtarla birlikte söylendiler "Manken, manken," diye ve çok sonra akıl ettiler onu manken olarak kullanmayı" (Atay, 2010: 17). Metalaşan dünyanın bir parçası olarak bir sıfat tamlamasına sahip olan "Beyaz Mantolu Adam"'n yerdeki suyun içine yansıyan görüntüsüyle öznelerin onu hayretle izlemeleri, mantoyu çekiştirmeleri, nesne tarafından ele geçirilmesiyle metalaştıklarının da en önemli göstergesidir. Hz. İsa'nın tüccarlar tarafından çarmıha gerilişi, beyaz paltolu adamın vitrine iğnelenerek asılmasıyla tekrar sahnelenir. Burada ayırt edilmesi gereken bedenleri ele geçiren öznelerin başka özneler üzerindeki iktidar gücünü kullanmasının temel dinamiği öznelerle beslenen nesnelerin devasa imparatorluklar haline gelmesidir.

Halk plajına giden Beyaz Mantolu Adam burada da göz hapsine alınır: "Burayı hemen terk edin" (Atay, 2010: 23) diye uyarır görevli adam, kadın mantosu ile gezmesi diğerlerine uygun gelmediği gibi ona da uygun gelmez, çevrenin rahatını ve huzurunu bozmasından dolayı dışarı çıkması istenir. Konuşamadığı için çevresine cevap veremeyen beyaz mantolu adama ithaf edilen sapık, deli, hasta gibi lafları gözleriyle cevap vermekten ileri gidemez gitmekte istemez. Toplum tarafindan tek şekilli olarak fark edilmesi, kalıplara uygun olmadığı için istenilmemesi, özne halinden nesne haline geçişi sırasında toplum ile karşı karşıya gelmesi, mutlak sonuna zemin hazırlar. "Denize değil!” (Atay, 2010: 24) beyaz mantolu adamın gözünün önünde gölgelerin olmadığı tek yer denizdir. Arkasında onu izleyen topluluğun önünde asıl dilsiz kendisinin olmadığını gösterircesine denize doğru ilerler, sonsuzluğa doğru yol almaya başlar.

Gogol'ün Palto'sundan çıkıp simülatif evrende kısa süre yaşayabilen Beyaz Mantolu Adam, Akaki'nin sessiz manifestosudur. Palto saflaşarak beyaz mantoya dönüşerek hem modernleşme eğilimi gösterir hem de kadınsılık üzerinden özneye mesaj gönderilir. Her iki eserde de nesne özne simülakrası yaratarak karakterleri ele geçirir ve onların hiçliğe sürüklenmesini sağlar. Dikkat çeken en önemli benzeşim karakterlerin nesneye sahip olduktan sonra yükselip düşmeleri ve varolan öznelerinin de toplumdan tama- 
men silinmesidir. Palto'da nesneden karaktere adlandırma gözükürken karakter paltoya hâkim olmanın peşindedir. Onunla yükselerek tümelin içerisinde yer alır ve onun yitip gitmesiyle tümelin içerisinde kaybolur gider. Beyaz Mantolu Adam'da karakterden nesneye adlandırma gözükürken nesne ölü taklidi yaparak karaktere sahip olur. Nötr bir pozisyonda varlığını sürdüren karakter önce tümelin içerisinde merak sonra yükselme ardından da silinip gider, hatta varlığı ve yokluğu arasında büyük bir illüzyon yaratarak hiçliğe yelken açar. İki eserinde dışsal okur üzerinde yarattığı etki aynı düzlemde gerçekleşir, simülasyon dünyasına ait olan nesneler sisteminde her şeyin yok olup gittiğidir. Burada unutulması gereken ayrıntı ise öznelerin nesne simülakrası ile ortadan tamamen kalkarken nesneler sisteminin aynı ve olduğu gibi işlevini sürdürüyor olmasıdır. Dışsal özne yani okur, edebi olanın içerisine girerek simülatif bir şekilde önceden her şeyi gözlemler ve deneyimleyerek sonuçlarını görebilir.

Palto'nun açtığı delikten Beyaz Mantolu Adam sessiz bir manifesto olarak çıkarken gerçek hayata uzanmayı sağlayacak diğer bir önemli yaratım olan Peter Schlemihl ile karş1laşırız. Kozmosun içinde illüzyonu saklayan gri paltolu adam, diğer paltolardan farklı olarak paltosunun içinden "elini cebine sokmuş ve gösterişsiz, hatta alçak gönüllü bir tavırla oradan değerli, sırma işlemeli bir Türk halısı çekip çıkarmaya başlamış bulunuyordu" (Chamisso, 1999: 7). Paltosunun cebinden dürbün, halı çıkarması Peter Schlemihl'den başka kimsenin ilgisini çekmiyor gibi görünür hatta çevresine gri paltolu adamı sorduğu zaman: "Şu terzinin iğnesinden kurtulmuş tireye benzeyen adam mı?" (Chamisso: s.8) cevabını alır, göründüğü üzere diğer palto sahipleri gibi gri paltolu adam da çevresi tarafından fark edilmeyen işe yaradığı zaman aranan ya da fark edilen kişidir. Peter Schlemihl'in gri paltolu adamı fark etmesi gibi o da Schlemihl'in farkındadır. Yanına gelerek, "Beyefendi açıklamama izin buyurun sizin güneşte ve şöyle soylu bir küçümsemeyle, önem bile vermeden yere firlattığınız o güzel, çok güzel gölgenizi olağanüstü şaşkınlık ve beğeniyle seyretme olanağını buldum, şu ayaklarınızın ucundaki muhteşem gölgenizi... Acaba şu gölgenizi bana bırakmaya razı olur muydunuz?" (Chamisso, 10) diye sorar. Schlemihl için önemsiz olan gölgesi gri paltolu adamın dikkatini çeker, gölgenin içinde öznelliği benliği olduğunun farkında olmayan Schlemihl talih kesesi karşllı̆ında gölgesini tereddüt etmeden verir: "Korkum ne kadar büyük olursa olsun, iki kelimeyle ruhumu avuçları içine almıştı" (Chamisso, 11). Metalaşan dünyada iktidar paradır ve talih kesesinin içinde sonsuz altın olma düşüncesi gölgeyi değersizleştirir, nesne görünüm değiştirerek gözünde özneliği yener. Althusser'in tabiiyet altına alma durumu burada göze çarpar.

Parası olmasına rağmen gölgesiz kalan Schlemihl: “Aman Allah'ım! Zavallı adamın gölgesi yok!” (Chamisso, 13) sözlerini duymaya başlar, dışarı çıkmaktan çekinir hale gelir, yardımcısı Bendel, onun gölgesi olmaya başlar. Sahte gölge kendi gölgesinin yerini tutmadığg gibi oynadığı iktidar rolünün de yavaş yavaş sonuna gelir. Gölgesinin olmadığının fark edilmemesi için geceleri dışarıya çıkmaya karar verir, nesneler sisteminde yitirdiği benliğini karanlık tarafa çekerek kazanmaya çalışır. Asıl gücün gölge olduğunun farkına vardıktan sonra gri paltolu adamdan gölgesini ister, gölgesine kolaydan sahip olan gri paltolu adam gölge karşıllğında: "Aşağıdaki imzama dayanarak ruhumu, tabii yolla 
vücudumdan ayrıldıktan sonra, bu kâğıdı taşıyan kişiye bağışlıyorum” der (Chamisso, 40). Kozmosta verilene karşılık her zaman alınacak bir şeyler vardır. Ruhunun istenmesi karşısında şaşkın olan Schlemihl gölgesinin alınması ile benliğinin yarım kalması, ruhunun alındıktan sonra ise artık Schlemihl diye birinin kalmayacağının farkındadır. Ruhunu vermemek için özgürlüğüne doğru yürümeye başlar, yolda giden gölgesini doldurmaya çalışır. “ ‘Ey gölge, sahibini mi arıyorsun?' diye düşündüm. 'Sahibin ben olayım!' Ve yakalamak için üzerine atıldım” (Chamisso, 45). Gölgesini yitirmesi üzerine başka gölgelerin sahibi olma arzusu duyar. Gri paltolu adam istediğini almak için gölgeyi serbest bırakır.

Buradaki palto kavramı nesnenin ele geçirdiği özneyi kullanarak başka özneler üzerinde yarattığı etki ve ele geçirme ile ilerler. Paltosundan cebine eline atarak ondan istenilen her şeyi veren gri paltolu adam, Alâeddin'in cini gibidir. Palto ise kozmosun kendisi pozisyonunu oynayan nesneler imparatorluğudur. Tanrısal bir işleve sahip olan gri paltolu adamın bu işlevini yerine getirmesini ve o pozisyona yükselmesini sağlayan şey ise paltodur. Palto isteyen herkese istediği şeyleri verir ve karş1lı̆̆ında önce gölgelerini alarak özneleri itibarsızlaştırır ardından da ruhlarına alarak dünyadaki yaşamlarına sona erdirir. Buradaki palto metalaşan dünyadaki özneleri avlayan sihirli lamba gibidir. Başıboş öznelerin, yaşamın verdiği değerlerin kıymetini bilmeyen karakterlerin, kendisinde olanın mükemmelliği yerine simülasyon olanları tercih eden tikellerin, nesneler sisteminde anında ve hemen tüketileceği, bu yapılırken de kutsal olanın dahi öznenin elinden alınacağı açık ve belirgin bir şekilde vurgulanır.

\section{Sonuç}

Kozmosun simülatif kurgusu üzerinde üç dansçı performanslarını Palto üzerinden sergilerken benzer dansları yaptılar gibi düşünülse de hepsi ayrı bir duruşu temsil ettiler. Aynı simülasyon içinde farklı bakışların birleştiği nokta çerçevesinde bir harita çizilir ve kozmosun sonsuz gerçekliği, sonul gerçeklikler halinde kurulan simülasyonlarla temsil edilerek yaşam adı verilen ve monad denilen gizil anahtarcıkların oluşturduğu yapılarla iç içe geçen hikâyeler oluşturulur. Buradan yola çıkarak evren anahtar deliklerinin yerleştirildiği boşluklarca kurulur. Kozmosun Palto'su şifrelerle kuşanmış bir tür sır alanıdır, tıpkı bir aynanın içine geçen görüntüler gibi palto da özneyi içine geçirir. Bütüncül bakılırsa nesnelerle ne kadar da iç içe yaşanıldığ ve onların özne üzerindeki etkisi net bir şekilde görülebilir. Öznelerini arayan paltolar, nesnelerin dünyasını özneye çekici gelecek hâle getirirler. İktidarı ele geçiren nesne özneyi nesneye çevirmek için, toplulukları sürüleşme olarak kullanmaya başlar, özneler kitleye ayak uydurmak için paltonun cazibesine kapılır ve onun peşinden sürüklenir. Çark dönmeye başlar, kozmos devinimini tamamlar, unutulmamalıdır ki çarkın sistemi birbirine bağlıdır.

Palto metaforuna Hegelvari yaklaşırsak Gogol'ün Palto'su simülasyon evrenine atılmış bir tez olarak okurun karşısına çıarken Oğuz Atay'ın Beyaz Mantolu Adam'1 anti-tez olarak görünür. Chamisso'nun Peter Schlemihl'1 ise sentez olarak karşımıza ç1kar. Gogol’ün paltosu sokaklarda bir tez olarak gezinirken diğer paltoların doğmasına da 
zemin hazırlar, sırayla doğan paltolar Gogol'ün paltosunun farklı yansımasıdırlar. Burada metinlerin yazım tarihleri öncelik ve sonralık sıralaması yoktur çünkü burada başrol oyuncusu oyunu en iyi oynayandır. Öznenin aradığı nesne olarak tez pozisyonunda olan Palto, anti tez olarak nesnenin aradığı özne olarak Beyaz Mantolu Adam'1 karşımıza çıkarır. İkisini de içerisinde barındıran ancak onlardan farklı olarak Nesne-Özne ortaklığıyla özneleri ele geçiren yapının sentezi olarak da Peter Schlemihl öyküsü öne çıkar.

Sonuç olarak bütün paltolar ortak bir noktada birleşir. Dünyanın kurgusu devam etmektedir ve Paltolar bu kurgunun zincirini oluşturmaktadır. Paltonun içinde iktidar, para, güç, narsisizm, vb. zaaflar saklanmaktadır. Palto insanların gizli noktalarına el basarak onları ortaya çıkarır ve istediğini almak için yine onların dilini kullanır. Öznenin yapmas1 gereken çok basittir, bir dâhil olamama, yadırganma ve çatışma problemi yaratmaktır. Burada acınması gereken palto kurbanı olan değil onun askısı olup sadece üzerinde taşımakla yükümlü olan ve hiçbir hikâyeye dâhil olamayanlardır. Bu sahte bir düzenek diyerek oradan ayrılanlarının simülatif ve bir o kadar gerçek olan hikâyesinin çarpıştığı bir kurmacadır. Nesnelerin ele geçirdiği ve simülasyon olarak kurulan dünyayı yerle bir etmek için Alice'in yaptığı gibi başkaldırmak, Don Kişot gibi sataşmak, Gogol'ün paltosunu sıyırıp tüm evrene firlatmak, Atay'ın Beyaz Mantolu Adam'1 gibi bir illüzyon yaratmak, Peter Schlemihl olarak gölgelerin gücü adına diyebilmek, kısacası sonlu gerçeklikte sonsuz monadlar yaratarak simülatif döngüye karşı devrimi başlatmak gerekir.

\section{Kaynaklar}

Adanır, O. (2008) Simülasyon kuramı üzerine notlar ve söyleşiler. İstanbul: Hayal Et.

Althusser, L. (1991) İdeoloji ve devletin ideolojik baskı aygıtları, (Çev. Y. Alp - M. Özışı). İstanbul: İletişim.

Atay, O. (2010) Korkuyu Beklerken. İstanbul: İletişim.

Baudrillard, J. (2008) Simgesel değiş tokuş ve ölüm. (Çev. O. Adanır). İstanbul: Boğaziçi Üniversitesi.

Baudrillard, J. (2011) Simülakrlar ve simülasyon. (Çev. O. Adanır). Ankara: Doğu Batı.

Baudrillard, J. (2012) Neden Her Şey Hâlâ Yok Olup Gitmedi. (Çev. O. Adanır). İstanbul: Boğaziçi.

Caroll, L. (2009) Alice harikalar diyarında ve aynadan İçeri. (Çev. K. E. Kına). İstanbul: İthaki.

Chamisso, A. V. (1999) Peter Schlemihl, İstanbul: Sentez.

Gogol, N. (1999) Üç öykü. (Çev. Orhan Veli - E. Güney). İstanbul: Cumhuriyet.

Nabokov, V. (2012) Nikolay Gogol. (Çev. Y. Yavuz). İstanbul: İletişim.

Saavedra, M. C. (2005) Don Quijote I. (Çev. R. Hakmen). İstanbul: YKY. 